\title{
A MARGINALIZAÇÃO DA ESCRITA FEMININA: A TRAJETÓRIA DE OBSTÁCULOS ENFRENTADOS PELAS ESCRITORAS
}

\section{MARGINALIZATION OF FEMALE WRITING: THE TRAJECTORY OF OBSTACLES FACED BY WRITERS}

\author{
Ana Maria Soares Zukoski' \\ [https://orcid.org/0000-0001-6231-701X] \\ DOI: 10.30612/raido.v14i35.11070
}

RESUMO: O presente trabalho tem por objetivo apresentar um mapeamento das dificuldades que as escritoras encontram para se inserir na seara literária, isto é, no campo literário e no cânone. Tais dificuldades se refratam nas premiaçôes literárias tendo por consequência uma lacuna na representaçăo de obras escritas por mulheres, quase nunca pleiteadas. A partir disso, realizamos um levantamento sobre os Prêmios: Jabuti, Machado de Assis e Camóes, a fim de verificar em que medida obras escritas por homens e mulheres săo agraciadas pelos prêmios e como a disparidade entre essas representaçôes sinalizam para a marginalizaçâo da escrita de autoria feminina. 0 trabalho está alicerçado nos pressupostos teóricos da Crítica Feminista e da Literatura de autoria feminina, com autores/as como Woolf (2014), Muzart (2011), Bourdieu (1996), Zolin (2015), Xavier (1999), Schmidt (1999), entre outros/as.

Palavras-Chave: Literatura de autoria feminina; Campo literário; Cânone; Premiaçóes literárias.

ABSTRACT: The present work aims to present a mapping of the difficulties that the writers find to insert themselves in the literary space, that is, in the literary field and in the canon. These difficulties are refracted in literary awards, resulting in a gap in the representation of works written by women, almost never pleaded. Based on that, we carried out a survey on the Awards: Jabuti, Machado de Assis and Camóes, in order to verify to what extent works written by men and women are graced by the awards and how the disparity between these representations signals the marginalization of writing by women. The work is based on the theoretical assumptions of Feminist Criticism and Literature of female authorship, with authors as Woolf (2014), Muzart (2011), Bourdieu (1996), Zolin (2015), Xavier (1999), Schmidt (1999), among others.

Keywords: Literature of female authorship; Literary field; Canon; Literary awards.

1 Doutoranda e mestra em Letras: Estudos Literários pela Universidade Estadual de Maringá - UEM. Aluna do Programa de Pós-Graduaçâo Lato Sensu em Estudos Literários pela Universidade Estadual do Paraná - Unespar - Campus de Campo Mourâo. Graduada em Letras Português/Inglês pela mesma instituiçáo.

Possui publicaçôes científicas em periódicos e capítulos de livros na área de literatura contemporânea. 


\section{CONSIDERAÇÕES INICIAIS}

O final do século XIX e o início do século XX ficou conhecido pelo surgimento da Primeira Onda Feminista nos Estados Unidos e na Inglaterra. Esse período foi marcado pelo ativismo literário, cultural e político, sobretudo pela luta do direito ao voto. 0 principal nome dessa época, a escritora britânica Virgínia Woolf, ao escrever o ensaio sistematizado em livro Um teto todo seu (1929), formulado a partir de duas palestras proferidas por ela em uma faculdade de mulheres, causou forte impacto no movimento feminista, ao denunciar, de forma veemente, as condiçōes das mulheres, ao longo dos séculos, para terem acesso ao mundo intelectual e à escrita, território predominantemente masculino.

O ensaio dispóe de uma personagem fictícia criada por Woolf, Mary Seton, que, ao longo de um dia, reflete sobre a temática: 'mulheres e ficçấo'. É por meio dessa personagem que a escritora britânica conduz as reflexôes propostas no texto e formula a sua principal tese: "uma mulher precisa ter dinheiro e um teto todo seu, um espaço próprio, se quiser escrever ficçăo; e isso [...] deixa sem soluçăo o grande problema da verdadeira natureza da mulher e da verdadeira natureza da ficçăo" (WOOLF, 2014, p. 12). A questăo financeira era algo bastante complicado se considerarmos que as leis de propriedade na Inglaterra do século XIX desfavoreciam as mulheres, inclusive impedindo-as de herdar patrimônios, nem dispor de nenhuma propriedade. Essas leis aparecem ilustradas em algumas obras de Jane Austen que refletem a sociedade vitoriana da época.

A complexidade da relaçăo entre mulher e escrita está situada mais no campo social do que na inexistência de aptidóes por parte das mulheres. As questôes sociais como a necessidade de uma renda fixa e um espaço próprio refletem a condiçấo de dependência financeira e a restriçăo ao âmbito privado da casa, situaçăo na qual muitas mulheres ainda se encontravam, cumprindo as funçôes de mâe e de esposa. Apesar de circunscrita ao espaço privado, sem propriedades, as autoras náo tinham nenhum lugar para chamar de seu.

Ao refletir a respeito das condiçōes para a criaçâo da arte, uma vez mais Woolf (2014, p. 41) questiona a condiçăo feminina: "Por que os homens bebem vinho e as mulheres água? Por que um sexo é tăo próspero e o outro tăo pobre? Que efeito tem a pobreza na ficçăo?". As dúvidas levantadas pela pesquisadora suscitam uma série de reflexôes que possuem como cerne a discriminaçăo das mulheres e a hegemonia masculina. A prosperidade do sexo masculino foi edificada certamente na subjugaçáo do sexo feminino que permaneceu excluído das mais diversas áreas, sendo necessário o surgimento das lutas feministas para inserir a mulher nesses campos, anteriormente exclusivos da autoridade masculina.

Dentre tais áreas, está situada a da escrita e do campo intelectual, vigorosamente resguardada pelo domínio masculino: "A única acusaçăo que posso fazer contra estudantes e professores de qualquer universidade que seja é a de eles terem afugentado meu pequeno peixe para proteger seus gramados cultivados durante trezentos anos a fio" (WOOLF, 2014, p. 15). A metáfora empregada pela autora avulta o esforço do campo intelectual em excluir as mulheres de seu domínio, pois 'meu pequeno peixe' pode ser tomado como as ideias e aspiraçôes femininas, ao passo que os 'gramados cultivados 
durante trezentos anos' representa a tradiçăo e os princípios dessa sociedade, assentada sobre os pilares do patriarcalismo. Quando os membros das universidades preferem 'afugentar' os 'pequenos peixes' que surgem, demonstram que as mulheres pensantes e produtoras de ideias e escritos năo eram bem-vindas na academia e no campo intelectual como um todo. Essa relaçăo construída por Woolf fala sobre um contraste inconciliável, pois peixes náo podem viver em gramados, assim como as mulheres náo podiam frequentar as bibliotecas e universidades.

A autora relaciona essa rejeiçăo nâo ao motivo apresentado, a inferioridade feminina, mas justamente ao contrário. Ela declara que a necessidade de o homem, representante da academia, afirmar constantemente a inferioridade das mulheres reflete que talvez "ele estivesse preocupado năo com a inferioridade delas, mas com a sua própria superioridade. Era isso que ele estava protegendo [...] porque era para ele uma joia do mais raro valor" (WOOLF, 2014, p. 53). Ao utilizar uma balança que coíbe a equidade, quanto mais características negativas e exclusôes sâo depositadas no prato do sexo feminino deixando-o baixo, mais alto estará o prato do sexo masculino, retratando uma imagem que nâo condiz com a realidade.

Acerca dessa relaçăo entre a degradaçâo das mulheres para ressaltar a superioridade masculina, Woolf (2014) utiliza a imagem do espelho, para tornar mais nítida a problemática social que envolve essa questăo: "As mulheres têm servido há séculos como espelhos, com poderes mágicos e deliciosos de refletir a figura do homem com o dobro do tamanho natural. Sem esse poder, provavelmente a terra ainda seria pântanos e selvas" (p. 54). Direcionar um olhar discriminatório às mulheres implica falso reconhecimento da superioridade masculina pelos próprios homens que, acreditando em tal falácia, sentem-se na incumbência de perpetuar essa ideologia, objetivando conservar essa posiçâo confortavelmente privilegiada.

Além das dificuldades culturalmente construídas pelo ideário social, baseadas na diferença entre homens e mulheres, a ensaísta frisa a questăo financeira, precária para as mulheres devido às poucas ocupaçôes que podiam desenvolver: "ganhei algumas libras endereçando envelopes, lendo para senhoras idosas, fazendo flores artificiais, ensinando o á-bê-cê para crianças [...] Eram essas as principais ocupaçôes disponíveis para as mulheres" (WOOLF, 2014, p. 57). As profissóes destinadas às mulheres năo poderiam, de alguma forma, alçá-las a uma autonomia, devido à baixa remuneraçăo ofertada, além de se configurar como um instrumento de controle, por parte da hegemonia masculina.

Aquelas que conseguissem romper o cerco e produzir obras teriam ainda de enfrentar o julgamento parcial do mundo: “O mundo năo dizia a ela, como dizia a eles: 'Escreva se quiser, năo faz diferença para mim'. O mundo dizia, gargalhando: 'Escrever? O que há de bom na sua escrita?"' (WOOLF, 2014, p. 78). Aos homens, na pior das hipóteses, lhe seria reservado indiferença. Já quanto às mulheres, na melhor das conjecturas, seu trabalho seria questionado acerca de sua validade e relevância. Julgadas mais pela autoria do que pelo valor estético, as obras de autoria feminina foram delegadas à marginalidade e à invisibilidade. A produçáo das mulheres permaneceria, até os dias de hoje, cerceada por afirmaçóes que dissuadissem a criaçấo: "Sempre haveria uma afirmaçâo dessas - você nâo pode fazer isso, você é incapaz de fazer aquilo - contra a qual protestar ou que se devia superar" (WOOLF, 2014, p. 80). 
Consciente das adversidades, propositalmente elaboradas a fim de desencorajar o ingresso das mulheres no mundo da escrita, Woolf (2014, p. 109) recorre ao vigor da literatura: "A literatura está aberta para todos. [...] Tranque as bibliotecas, se quiser; mas năo há portóes, nem fechaduras, nem cadeados com os quais você conseguirá trancar a liberdade do meu pensamento". Ao afirmar sua liberdade de pensamento, a escritora britânica encoraja o fortalecimento da escrita de autoria feminina que poderá desenvolver-se, sendo necessário antes lutar pelo seu reconhecimento.

A literatura também dispóe da funcionalidade de humanizar, como bem pontua Antonio Candido: “Toda obra literária é antes de mais nada uma espécie de objeto, de objeto construído: e é grande o poder humanizador desta construçăo, enquanto construçăo" (1989. p. 114). Portanto, mulheres produzindo literatura implicaria em processo de humanizaçầo que atingiria năo apenas as escritoras, mas todos aqueles que tivessem acesso e lessem seus escritos. Também Woolf (2014) compartilha a mesma visăo: "Assim, quando lhes peço que escrevam mais livros, estou a incitá-las a fazer o melhor para vocês e o melhor para o mundo como um todo" (p. 153). Tal afirmaçăo, enunciada em uma de suas palestras, objetiva demonstrar às mulheres da plateia que o fato de elas já se encontrarem inseridas na universidade, por si, já lhes possibilita maiores oportunidades. Assim, Woolf as exorta a serem independentes e a pensarem por si mesmas, conscientizando-as da perspectiva de exercerem uma grande influência no futuro, por meio de suas lutas e principalmente de seus escritos.

\section{CAMPO LITERÁRIO, CÂNONE E PREMIAÇÕES: MECANISMOS A SERVIÇO DO PODER PATRIARCAL}

As dificuldades apontadas por Virginia Woolf em 1915 nâo foram superadas, mesmo com os avanços e melhorias que os movimentos feministas, por meio de lutas alcançaram: "No mundo andrôcentrico ${ }^{2}$ em que vivemos, o lugar das mulheres da cultura está reservado a um plano secundário, seja pela falta de protagonismo no momento da produçấo cultural ou pela falsa representaçăo das mulheres em sua diversidade" (VITÓRIA; ZELIC, 2015, p. 76). Quando se trata da produçáo realizada pelas mulheres, independente de qualquer que seja o campo das artes em questâo, a invisibilidade está sempre a rondar, disposta a manter as mulheres longe do reconhecimento necessário para adentrar o campo intelectual enquanto protagonistas. Vitória e Zelic (2015, p. 89) afirmam que é imprescindível "unir as amplas possibilidades da literatura às múltiplas realidades percebidas pela ótica das mulheres, que por viverem em um sistema desigual, possuem outra perspectiva". Certamente, a literatura de autoria feminina exterioriza as mazelas enfrentadas pelas mulheres, mas năo se reduz a isso, possuindo tanto valor estético quanto a literatura produzida por homens. Por isso, de acordo com as autoras "o incentivo à criaçăo e difusăo [...] é necessário para ampliar as possibilidades de encontro entre as vidas vividas, as narradas e as desejadas pelas mulheres de

2 O androcentrismo foi um termo criado pelo sociólogo Lester F. Ward em 1903 e estabelece relaçóes com o patriarcalismo. Diferentemente do último, o primeiro náo se atém apenas aos privilégios masculinos, pois é voltado para as perspectivas que consideram o homem como o cerne de análise do todo. De acordo com o sociólogo francês Pierre Bourdieu: "a visáo androcêntrica impóe-se como neutra e náo tem necessidade de se enunciar em discursos que visem legitimá-la" $(2015,18)$. 
diversas partes do mundo" (VITÓRIA; ZELIC, 2015, p. 89). A falta de apoio dificulta a inserçăo das mulheres no campo literário, pois além de năo incentivar a produçâo das mulheres, essas encontram barreiras nas etapas de publicaçăo, devido à misoginia que permeia o campo editorial.

Essas dificuldades para publicar, encontradas pelas autoras, é de fácil percepçâo quando analisamos criticamente os catálogos de grandes editoras. A abundância de obras escritas por homens em contraposiçâo à minoria de escritoras presentes é bastante nítida. Isso nos encaminha a ideia de que a autoria influencia diretamente na recepçáo da obra. O texto Cultura Letrada: literatura e leitura (2006) de Abreu aborda essa relaçăo: "Faz toda a diferença [...] saber quem é o autor [...] A assinatura confere autoria à obra e a inscreve em uma convençấo a partir da qual os críticos e o público especializados olham para ela" (ABREU, 2006, p. 45). A assinatura da mulher em sua criaçăo artística ocasiona um olhar diferenciado para a obra, isto é, um novo critério é levado em consideraçăo para a sua avaliaçăo, e depreciaçăo. Essa questâo acarreta o problema de que é a assinatura feminina que se constitui como o motivo para a desvalorizaçâo da obra, ou seja, o texto nâo é avaliado pelos critérios estéticos, pois o fato de ser uma mulher a tê-lo escrito é o fator mais levado em consideraçăo para a avaliçâo.

Devido a essa negativa e intransigente acolhida, principalmente na esfera literária, muitas autoras, no decorrer do século XIX, buscaram nos pseudônimos masculinos, dar uma chance a suas obras de serem avaliadas de forma imparcial, como é o caso de Charlotte Brontë, escritora do famoso romance Jane Eyre, publicado em 1847, sob o pseudônimo Currer Bell. Para Duarte, o uso desse recurso por parte das mulheres servia como uma "forma de driblar a crítica e os leitores e, ao mesmo tempo, se protegerem da opiniăo pública" (1997, p. 54). Assim sendo, a publicaçăo do romance Jane Eyre, com uma suposta autoria masculina, possibilitou que acontecesse o reconhecimento do valor estético da obra, que se estabeleceu como um grande sucesso logo após sua publicaçăo. Do contrário, se tivesse sido publicado sob o nome real da autora, é provável que o romance náo tivesse sido avaliado de forma justa. Outra autora que nâo conseguiu reconhecimento pela sua obra foi Mary Anne Evans, que se utilizou do pseudônimo George Elliot, tendo publicado Midllemarch (1872) sob um nome masculino. É significativo que a autora tenha lançado mâo de tal recurso e, diferentemente de outras autoras, náo tenha assumido seu verdadeiro nome posteriormente. Suas obras abordavam a questăo da voz da mulher por meio de suas personagens que também possuíam aspectos autobiográficos.

Duarte aborda essa e outras dificuldades encontradas pelas mulheres para publicar suas obras no texto "O cânone e a autoria feminina" (1997). A pesquisadora coloca luz no nome de inúmeras autoras como Maria da Felicidade do Couto Browne, Auta de Souza e Emily Dickinson, que náo conseguiram ter suas obras publicadas em vida devido à desvalorizaçâo e controle dos homens que as cercavam. Essa última tendo publicado apenas três poemas quando viva e tendo reconhecimento após sessenta anos de sua morte. Duarte (1997) comenta sobre o fato de um escritor apagar as possibilidades de reconhecimento de escritoras da mesma família: "Năo é por acaso que de algumas só se sabe que foi 'irmă de Balzac', 'esposa de Musset', ou 'măe de Lamartine' e mal se conhecem seus nomes ou seus escritos" (p. 55). Estarem à sombra desses grandes homens, acabou por sufocar essas escritoras, sobretudo, em virtude das relaçóes familiares nâo fomentar o surgimento de outros escritores, principalmente, se fossem mulheres. A 
essas escritoras, apagadas pelas sombras, nem mesmo o próprio nome foi permitido conhecer, permanecendo ligadas ao nome daquele que as ofuscava. Tal ligaçăo maximiza o ideário de que as mulheres só poderiam ser conhecidas como posse de algum homem, seja marido, pai ou irmâo, como é o caso de Elizabeth Barrett Browning, que ficou mais conhecida pelo seu casamento do que pelas suas obras.

O contexto de produçấo e difusâo das obras de autoria feminina europeias manifestava-se de forma bastante hostil contra essas autoras brancas, no entanto, a situaçâo das mulheres negras, indígenas, entre outros grupos minoritários configurava-se como ainda mais complexo, devido ao peso de duplas e triplas formas de opressâo que recaíam sobre esses grupos; em outras palavras, se para as mulheres brancas já era difícil escrever e publicar, para as representantes dos demais grupos minoritários era mais ainda.

O século XX foi de suma relevância para os movimentos feministas, devido à ascensăo das mulheres nos mais diversos campos. Muzart discorre sobre alguns dos avanços das autoras: "Somente nesse século, as escritoras foram conquistando um espaço maior, pois mesmo que tenham publicado no século XIX, faltou-lhes algo importante: o respeito năo como senhoras distintas mas como distintas escritoras" (2011, p. 19). Mesmo tendo sido um século bastante produtivo, a produçăo literária feminina năo se iniciou exclusivamente nesse século no Brasil. Contrariamente, houve um número abundante de escritoras brasileiras no século XIX, contudo, essas foram condenadas à invisibilidade até Muzart realizar o trabalho de resgatá-las. Os resultados da pesquisa foram sistematizados sob o título Escritoras brasileiras do século XIX: antologias contando com três volumes e apresentando em suas mais de novecentas páginas o espantoso número de mais de cem autoras, apagadas pelo tempo e pelo preconceito. Schmidt (2019, p. 66) discorre sobre a importância desse trabalho de resgate que "chegou para romper o monólogo masculino, nas palavras de Mary Louise Pratt, 'ou, pelo menos para desafiar a sua reivindicaçâo de monopólio da cultura, da história e da autoridade intelectual"'.

A produçăo feminina, apesar de numerosa, enfrentava (e ainda enfrenta) a dificuldade de adentrar o campo literário. Muzart (2011), ao analisar os manuais de teoria literária, ratifica que "as mulheres estăo segregadas num capítulo [...]. Parece-nos que, embora fique evidente o esforço para incluí-las para que sejam aceitos os seus nomes, há ao mesmo tempo uma divisâo que as coloca no limbo" (p. 20). As poucas escritoras que conseguiram romper o cerco e entrar no campo literário, náo possuem o mesmo prestígio e reconhecimento dos autores homens. Separá-las em um único capítulo nesses manuais de teoria literária, configura uma nova forma de exclusăo, isto é, colocam todas as escritoras em uma parte restrita do livro apenas para năo haver reclamaçôes sobre a falta da representatividade feminina. Essa divisâo năo agradou as mulheres que escrevem, pois reflete que năo há uma verdadeira incorporaçăo dos escritos de autoria feminina, revelando que a diferença entre homens e mulheres continua sendo utilizada para marginalizar as últimas.

Bourdieu, em As regras da arte: gênese e estrutura do campo literário (1996) nos apresenta conceito de campo literário e tece reflexóes sobre o mesmo a partir do romance de Flaubert e das poesias de Baudelaire. O teórico compreende campo literário como "uma rede de relaçôes objetivas (de dominaçăo ou de subordinaçăo, de complementaridade ou de antagonismos etc) entre posiçôes" (BOURDIEU, 1996, p. 261). 0 crítico constrói, ao longo da obra, a tese de que é necessário fazer parte do 'jogo' literário e 
para conseguir jogar é necessário compreender como essas relaçōes decorrem e, assim atender as regras, adentrando o campo literário, destacando que se trata de "um campo de forças a agir sobre todos aqueles que entram nele, e de maneira diferencial segundo a posiçăo que aí ocupam" (p. 262). O campo literário, com suas complexas relaçôes, procede de forma diferenciada conforme quem ou o status que a pessoa que conseguiu adentrar dispóe.

O 'jogo' literário ao qual o público leitor, os agentes literários, o mercado, os editores, e, principalmente, os escritores precisam aprender a jogar está subordinado aos esquemas de percepçăo e apreciaçấo que "estruturam a percepçâo do jogo e das apostas e reproduzem em sua lógica própria as divisóes fundamentais do espaço das posiçōes (por exemplo, arte 'pura'/ arte 'comercial', 'boêmio'/'burguês', 'margem esquerda'/ 'margem direita' etc)" (BOURDIEU, 1996, p. 267). Certamente, compreender a lógica do jogo é fundamental, para que o autor consiga preencher os requisitos que o colocaráo dentro do campo literário. Contudo, a própria lógica do jogo já prevê divisóes, que dificultarâo ou facilitarâo a entrada.

Sobre a estrutura do campo literário brasileiro, Miceli (apud ZOLIN, 2015, p. 103) coloca que essa foi concebida durante as primeiras décadas do século XX e está alicerçada, nâo somente em instâncias de legitimaçâo e classificaçăo, artísticas e literárias, como o mercado editorial, as academias literárias, a imprensa e as revistas culturais, porém, especialmente, na relaçáo de sujeiçáo com o Estado, que interferia de forma significativa, solicitando a inserçăo de autores específicos na lista das editoras até meados dos anos 1930.

Zolin, em "O habitus e o espaço dos possíveis: a literatura de autoria feminina paranaense/brasileira" (2015) problematiza questôes contundentes sobre o campo literário conceituado por Bourdieu, afunilando as discussōes para a ficçăo feminina. Se o campo literário reconhece determinados autores é porque eles "conseguiram internalizar o habitus que lhe confere os contornos [...] adquiriram o conhecimento necessário acerca dos sistemas que regem o campo, convertendo-os no capital simbólico responsável pela inserçăo deles aí" (ZOLIN, 2015, p. 104). Mas será que, para as mulheres que escrevem, basta saber jogar o 'jogo' literário? Para Zolin, "no caso das escritoras paranaenses, nâo se trata apenas de ter talento para jogar com o habitus do campo, assimilando-lhe o funcionamento, lançando măo dele em favor de si, há que se conquistar, antes, o direito de jogar" (2015, p. 104).

Ao que nos parece, todas as escritoras, năo apenas as paranaenses, encontram um obstáculo a mais do que os homens quando dessa empreitada, isto é, precisam lutar primeiro pelo direito de poder participar do jogo. Daí, a primeira dificuldade para a inserçăo das mulheres no campo literário brasileiro, que se estabelece enquanto um espaço excludente.

Regina Dalcastagnè coordenou uma pesquisa que focalizava a representaçấo da personagem no romance brasileiro, compreendendo como corpus os romances publicados entre 1990 e 2004, por três grandes editoras do Brasil: Companhia das Letras, Editora Record e Editora Rocco. Os resultados elucidaram que o campo literário apresenta uma perspectiva "social enviesada, tanto mais grave pelo fato de que os grupos que estâo excluídos da voz literária săo os mesmo que săo silenciados nos outros espaços de produçăo do discurso - a política, a mídia, em alguma medida ainda o mundo 
acadêmico" (DALCASTAGNÈ, 2005, p. 64). Ao demonstrar, por meio dos resultados, que determinados segmentos sociais permanecem marginalizados e excluídos do âmbito literário, e dos demais meios que possibilitariam um direito à voz, o campo literário brasileiro deslegitima os escritos de minorias como as mulheres, os negros, os indígenas e os homossexuais, entre outros.

A pesquisa 'A literatura de autoria feminina paranaense', mesmo que restrita à produçâo literária do Estado do Paraná, dirigida por Zolin, aponta para a dificuldade das mulheres em se inserirem no campo literário. De 563 obras catalogadas, 55\%, ou seja, 310 obras foram produzidas por meio de ediçôes independentes, isto é, custeadas pelas próprias autoras ou por iniciativas particulares. Isso "é sinal de que a barreira do habitus do campo literário brasileiro [...] năo tem sido facilmente assimilada pelas escritoras [...] apontando para a necessidade de democratizaçăo do fazer literário" (ZOLIN, 2015, p. 105). Romper o cerco misógino que envolve o campo literário nâo é uma tarefa simples e nâo depende do valor estético das obras de literatura de autoria feminina; contrariamente, diz respeito a um problema dos âmbitos social e cultural.

A dificuldade para a inserçáo das autoras no campo literário é imensa. Contudo, no que tange ao cânone elas se multiplicam, uma vez que é ele que seleciona e determina quais obras literárias possuem alto valor estético e săo dignas de serem consideradas como clássicos. De acordo com Reis, "o conceito de cânon implica um princípio de seleçâo" (1992, p. 70). Ao acarretar um 'princípio de seleçăo', o cânone é transformado em um mecanismo de exclusăo, estando vinculado ao poder e as questóes sociais. A aquele que é investido o poder de selecionar, o fará a partir de seus pressupostos e interesses, ideologicamente marcados.

Portanto, "[o cânone] está a serviço dos mais poderosos, estabelecendo hierarquias rígidas no todo social e funcionando como uma ferramenta de dominaçâo" (REIS, 1992, p. 73). Percebemos aí o legitimar da perpetuaçâo da exclusâo de determinados grupos sociais, étnicos e sexuais, e que esse mecanismo está assentado nos pressupostos ideológicos do patriarcalismo e da dominaçăo masculina. Para Reis (1992, p. 73), o maior problema náo se situa no corpus dos textos canonizados, mas sim, no próprio processo de canonizaçăo, intrinsecamente ligado às malhas de poder, que precisam ser desfeitas. Nâo basta, simplesmente, inserir algumas obras de autoria feminina, negra, indígena ou homossexual no cânone para que esse se democratize. É necessário, primeiramente, compreender e desfazer as questōes sociais e de poder que envolvem esse mecanismo, transformando-o de opressor a democratizador.

A premência de problematizar o cânone e seus mecanismos de poder é abordada por Xavier, no texto "Para além do cânone" (1999). De acordo com a pesquisadora (p. 15) se "atentarmos para o fato de que [...] há sempre um mecanismo que controla os meios de representaçáo, estabelecendo conexôes entre saber e poder político, nos damos conta da importância de se questionar aquelas categorias". Uma vez desnudada as relaçôes com o poder e a dominaçâo masculina, é necessário o questionamento dessas categorias, que tem por funçăo, manter a produçăo feminina, entre outras, à margem, tanto do cânone como do campo literário. A indagaçăo sinaliza a tentativa de desfazer, ou ainda, aniquilar as malhas de poder e possibilitar a popularizaçấo da literatura. Todavia, essas redes de poder foram muito bem construídas e assentadas no discurso ideológico patriarcal, e rompê-las demanda um longo e árduo processo. 
A relutância em aceitar que as mulheres escrevem obras literárias de grande valor estético é evidenciada nas premiaçōes literárias que praticamente nâo condecoram autoras. Com o intuito de fundamentar a asserçâo sobre a dificuldade de inserçăo de escritoras no campo literário e no cânone, constatamos que os nomes laureados nos três principais prêmios de literatura em língua portuguesa săo masculinos: Prêmio Jabuti, Prêmio Machado de Assis e Prêmio Camóes. Os dois primeiros, restritos à produçáo brasileira, e o terceiro contemplando toda a produçăo literária em língua portuguesa.

O Prêmio Jabuti ${ }^{3}$ foi idealizado pelos dirigentes da Câmara Brasileira do Livro, representados pelo presidente Edgar Cavalheiro e pelo secretário Mário da Silva Brito por volta de 1958, época obscura devido à falta de recursos e de baixa circulaçăo para o mercado editorial. Teve sua primeira edição em 1959 e segue premiando autores até os dias de hoje. Possui maior abrangência que os demais prêmios, pois valoriza năo apenas os escritores, mas enfatiza a qualidade do trabalho de todos os segmentos enredados na criaçăo e produçâo de livros. Devido a essa grande amplitude, detivemos a análise que segue apenas a uma categoria: romance.

Nessa categoria, no período entre 1959 a 2019, o Prêmio Jabuti distribuiu 115 prêmios. Desse total, 96 premiados sâo do sexo masculino, correspondendo a 83,4\%. Apenas 19 prêmios foram destinados a mulheres que escreviam ${ }^{4}$, representando 16,6\%. A produçấo literária de autoria feminina náo alcançou nem $20 \%$ de reconhecimento pelos críticos e especialistas em literatura, responsáveis pela avaliaçấo e premiaçâo das obras. 96 autores premiados versus 19 autoras premiadas evidencia o quâo pequena é a inserçâo das mulheres no campo literário, aproximadamente 4 vezes menor do que a participaçáo masculina. Essa baixa representatividade de mulheres escritoras premiadas denota que as obras, por elas produzidas praticamente náo circulam no campo literário, com uma recorrência ainda menor no âmbito acadêmico, permanecendo no limbo da invisibilidade. Isso justifica a falta de autoras contempladas, pois obras que năo alcançam o reconhecimento ao menos no campo literário, náo serầo objeto de análise para premiaçôes. Em algumas ediçôes o Prêmio Jabuti estabeleceu as categorias de $1^{\circ}, 2^{\circ}$ e $3^{\circ}$ lugar. A tabela a seguir sistematiza a quantidade de premiados por categorias, separada pelo sexo.

\section{Tabela 01 - Sexo da(o) autora(or) x Classificação}

\begin{tabular}{|c|c|c|c|c|c|c|}
\hline $\begin{array}{c}\text { Sexo da(o) autora(or) } x \\
\text { Classificação }\end{array}$ & $1^{\circ}$ lugar & $2^{\circ}$ lugar & $3^{\circ}$ lugar & $\begin{array}{c}\text { Menção } \\
\text { Honrosa }\end{array}$ & $\begin{array}{c}\text { Sem } \\
\text { colocação }\end{array}$ & TOTAL \\
\hline Masculino & 16 & 17 & 13 & 2 & 48 & 95 \\
\hline Feminino & 3 & 1 & 4 & 0 & 11 & 19 \\
\hline TOTAL & 19 & 18 & 17 & 2 & 59 & 115 \\
\hline
\end{tabular}

Fonte: Prêmio Jabuti

3 Informaçóes retiradas do site: <https://www.premiojabuti.com.br/historia/>. Acesso em 12 fev. 2019.

4 As autoras agraciadas com o Prêmio Jabuti foram: Maria de Lourdes Teixeira (1961 e 1970); Lenita Miranda de Figueiredo (1971); Lygia Fagundes Telles (1974); Clarice Lispector (1978); Maria Adelaide Amaral (1987); Maria Alice Barroso (1989); Zulmira Ribeiro Tavares (1991); Raquel de Queiroz (1993); Sônia Coutinho (1999 com o $2^{\circ}$ lugar); Patrícia Melo (2001); Ana Miranda (2003); Nélida Piñon (2005 com o $1^{\circ}$ lugar); Beatriz Bracher (2008 com o $3^{\circ}$ lugar); Verônica Stigger (2014 com o $3^{\circ}$ lugar); Maria Valéria Rezende (2015 com o $1^{\circ}$ lugar e 2017 com o $3^{\circ}$ lugar); Sheyla Smanioto (2013 com o $3^{\circ}$ lugar) e Carol Bensimon (2018). 
Os resultados expostos na tabela evidenciam que a representatividade feminina na principal colocaçăo, $1^{\circ}$ lugar, é bastante restrita, tendo apenas 3 romances de autoria feminina alcançado essa colocaçăo, em contraposiçăo a 16 romances de autoria masculina, um total de mais de 5 vezes maior. A porcentagem de mulheres que alcançaram o primeiro lugar está muito próxima à calculada quando consideramos todos os romances premiados, independentemente de classificaçăo, permanecendo um contundente distanciamento entre homens e mulheres que escrevem. 0 fato de apenas 3 autoras terem sido premiadas em $1^{\circ}$ lugar demonstra como é custoso reconhecer o trabalho de uma mulher como o melhor e, sobretudo, melhor do que o de homens.

Dentre as escritoras premiadas, em números, sâo 17 mulheres, pois duas das autoras foram premiadas duas vezes: Maria Valéria Rezende venceu a primeira vez, na colocaçấo $1^{\circ}$ lugar em 2015 com o romance Quarenta dias e a segunda vez, na colocaçấo $3^{\circ}$ lugar em 2017 com a obra Outros Cantos, e Maria de Lourdes Teixeira, campeá em 1961 com o romance Rua Augusta e também em 1970 com a obra O Pátio das Donzelas. Receber um prêmio, com a notoriedade do Prêmio Jabuti, oportuniza de forma significativa a inserçâo da autora no campo literário, o que explica o fato de duas autoras terem sido premiadas mais de uma vez.

A Academia Brasileira de Letras promoveu importantes premiaçōes literárias, entre elas: Prêmio Machado de Assis, Prêmio José Lins do Rego, Prêmio Francisco Alves, Prêmio Abgar Renault, entre outros. Salta aos olhos que os nomes dos prêmios homenageiam grandes escritores brasileiros. Năo desprezando o mérito de tais autores, surgem as seguintes indagaçóes: No Brasil, năo existem escritoras dignas de serem homenageadas, batizando com seus próprios nomes os Prêmios orquestrados pela Academia Brasileira de Letras? Por que os prêmios agraciam apenas os escritores? Esses questionamentos desembocam novamente na questăo da segregaçăo das mulheres que escrevem e de seus escritos. Reconhecemos a grandiosidade dos autores, mas é inverossímil que inexistam escritoras com, minimamente, o mesmo talento literário que os homens. $\mathrm{O}$ fato de apenas escritores terem seus nomes vinculados aos prêmios literários demonstra que o preconceito em relaçâo às escritoras ainda permeia os bancos da Academia Brasileira de Letras. O machismo é evidenciado com o fato de Raquel de Queiroz, a primeira mulher a ocupar uma cadeira, ter conseguido ingressar apenas em 1977, isto é, 80 anos após a fundaçâo da Casa.

Em 1911, foi criado o Prêmio Machado de Assis, ${ }^{5}$ idealizado para ser distribuído anualmente e julgado por uma comissâo, que definiria o nome do campeâo. $O$ site da Academia Brasileira de Letras disponibiliza os campeóes do referido prêmio, pelo período de 1941 a 2017. Ao todo, foram distribuídos o total de 72 prêmios, sendo 63 conferidos a autores do sexo masculino, correspondendo a 87,5\% e apenas 9 atribuídos a escritoras, ${ }^{6}$ totalizando $12,5 \%$. A discrepância entre a quantidade de prêmios outorgados a homens e a mulheres, escritores por profissăo, evidencia, assim como no caso do Prêmio Jabuti, que as autoras nâo conseguem com que suas obras alcancem o mesmo nível de circulaçấo que as obras de autoria masculina.

\footnotetext{
5 Informaçóes retiradas do site: http://www.academia.org.br/academia/premios Acesso em 12 fev. 2019.

6 As autoras homenageadas com o Prêmio Machado de Assis foram: Tetra Teffé (1941); Dinah Silveira de Queiroz (1954); Raquel de Queiroz (1958); Cecília Meireles (1965); Carolina Nabuco (1978); Gilka Machado (1979); Henriqueta Lisboa (1984); Maria Clara Machado (1991) e Ana Maria Machado (2001).
} 
O Prêmio Camóes de Literatura, ${ }^{7}$ estimado como o mais importante prêmio da língua portuguesa, foi instaurado em 1988 e objetiva consagrar um autor pelo conjunto de sua obra. Para isso, a obra precisa ter colaborado para o engrandecimento do patrimônio literário e cultural lusófono. Compreende autores da Comunidade dos Países de Língua Portuguesa, integrando em sua comissâo julgadora representantes de Brasil e Portugal, além dos demais países que possuem como idioma oficial a língua portuguesa.

De 1988 a 2019, o Prêmio Camóes distribuiu o total de 31 prêmios, 25 sendo concedidos a autores, somando 80,6\% e apenas 6 foram conferidos a escritoras, ${ }^{8}$ correspon- $^{-}$ dendo a 19,4\%. Novamente, está presente um abismo entre o número de mulheres e de homens premiados, denunciando que a dificuldade para inserçăo no campo literário năo é uma particularidade das escritoras brasileiras.

Os países com representantes premiados foram: Brasil, Portugal, Moçambique, Angola e Cabo Verde. O Brasil foi o mais premiado, conquistando 13 prêmios, seguido por Portugal com 11, Moçambique com 3 e Angola e Cabo Verde, com 2 prêmios cada. A tabela a seguir sistematiza os resultados, apresentando, além dos prêmios por países, o sexo da(o) autora(or) premiada(o).

Tabela 02 - Sexo da(o) autora(or) x País de origem da(o) autora(or)

\begin{tabular}{c|c|c|c|c|c|c}
$\begin{array}{c}\text { Sexo da(o) autora(or) } \mathrm{x} \text { País } \\
\text { de origem da(o) autora(or) }\end{array}$ & Brasil & Portugal & Moçambique & Angola & $\begin{array}{c}\text { Cabo } \\
\text { Verde }\end{array}$ & TOTAL \\
\hline Masculino & 11 & 7 & 3 & 2 & 2 & 24 \\
\hline Feminino & 2 & 4 & 0 & 0 & 0 & 6 \\
\hline TOTAL & 13 & 11 & 3 & 2 & 2 & 31 \\
\hline \multicolumn{7}{c}{ Fonte: Prêmio Camões } \\
\end{tabular}

Os resultados demonstram que dos 5 países premiados, apenas 2 foram representados por mulheres, e náo coincidentemente, os 3 países que menos possuem prêmios, sâo geograficamente localizados no continente africano. Para as autoras africanas, outro obstáculo é somado para além do gênero: o fato de serem mulheres negras. Escritoras africanas com obras literárias expressivas como as escritoras provenientes do país Sáo Tomé e Príncipe: Alda do Espírito Santo e Manuela Margarido e as moçambicanas Noémia de Souza e Paulina Chiziane năo foram agraciadas com o prêmio, apesar de possuírem obras de rico valor estético e literário. A cor da pele e o sexo săo utilizados para marginalizar duplamente essas mulheres, que năo conseguem com que seus escritos alcancem um alto nível de circulaçâo no campo literário.

Esse duplo preconceito que as mulheres negras precisam enfrentar náo está restrito apenas ao continente africano. No Brasil, temos o recente exemplo da escritora Conceiçăo Evaristo, que em 2018 candidatou-se para uma cadeira na Academia Brasileira de Letras. Se tivesse ganhado, ela seria a primeira escritora negra a fazer

7 Informaçôes retiradas do site: <https://www.bn.gov.br/explore/premios-literarios/premio-camoesliteratura>. Acesso em 12 fev. 2019.

8 As autoras escolhidas para receber o Prêmio Camóes foram: Raquel de Queiroz (1993); Sophia de Mello Breyner Andresen (1999); Maria Velho da Costa (2002); Agustina Bessa-Luís (2004); Lygia Fagundes Telles (2005) e Hélia Correia (2015). 
parte desse seleto grupo de escritores renomados. Contudo, Evaristo, recebeu apenas 1 voto, ao passo que Cacá Diegues recebeu 22 e Pedro Corrêa do Lago 11. Mesmo com uma campanha que colheu 25 mil assinaturas on-line, em apoio da candidatura da escritora negra, a Academia Brasileira de Letras demonstrou ser um espaço misógino e racista.

Os dois únicos países que tiveram autoras premiadas foram o Brasil e Portugal. A diferença entre ambos é contundente, pois mesmo tendo um título a menos, Portugal teve o dobro de autoras premiadas. As mulheres portuguesas correspondem aproximadamente a $36,36 \%$, ao passo que as brasileiras ficam restritas a um número bem menor: 15,38\%. A representatividade de escritoras portuguesas está distante do ideal, mas se comparado com a brasileira, elas conseguem, em alguma medida, uma maior inserçáo no campo literário.

Ao cruzar os dados referentes aos Prêmios: Jabuti, Machado de Assis e Camóes, há um total de 218 premiaçôes. Desse total, apenas 30 foram destinados a escritoras, totalizando aproximadamente $13,76 \%$, sendo 25 o número de mulheres que receberam os prêmios e a diferença justificada pelo fato de algumas autoras terem sido premiadas mais de uma vez, conforme ilustra a tabela abaixo:

Tabela 03 - Quantidade de prêmios por autora

\begin{tabular}{|c|c|c|}
\hline Quantidade de prêmios & Freq. & $\%$ \\
\hline Um & 21 & $84,0 \%$ \\
\hline Dois & 3 & $12,0 \%$ \\
\hline Três & 1 & $4,0 \%$ \\
\hline TOTAL & 25 & $100 \%$ \\
\hline
\end{tabular}

Fonte: Prêmios Jabuti, Machado de Assis e Camões

Raquel de Queiroz foi a autora mais premiada, tendo ganhado uma ediçâo de cada um dos prêmios. A conquista desses prêmios possibilitou que a obra da escritora alcançasse a visibilidade, motivo que empreendeu, além do alto valor estético de suas obras, sua representaçâo no cânone da literatura brasileira, recebendo o merecido reconhecimento pelos seus escritos ${ }^{9}$. Assim como Raquel, Lygia Fagundes Telles também conseguiu romper com as malhas de poder e preconceito, e foi campeá duas vezes, laureada nos prêmios: Jabuti e Camóes.

Maria Valéria Rezende e Maria de Lourdes Teixeira, bicampeăs no ," năo atingiram o mesmo status que as duas primeiras escritoras, canonizadas pela crítica literária brasileira. Maria de Lourdes Teixeira acabou sucumbindo no esquecimento, sem ter suas obras estudadas e lidas nas academias e nas escolas. Já Maria Valéria Rezende vem despontando na seara literária contemporânea com seus escritos constando na lista de obras literárias exigidas para o vestibular de diversas universidades. Assim, a importância de ter suas obras reconhecidas pelo campo literário se desnuda, pois se

9 Seu último romance publicado, Memorial de Maria Moura, a exemplo da obra de Jorge Amado, foi transformado em minissérie pela Rede Globo, alcançando um grande sucesso e sendo exibida dois anos após a sua publicaçăo, em 1994. 
as mulheres năo forem reconhecidas como escritoras, a marginalizaçăo continuará a permear a literatura de autoria feminina.

\section{CONSIDERAÇÕES POSSÍVEIS}

Mulheres e palavras: desde sempre uma sinuosa relaçáo. As diversas curvas que precisaram ser superadas para que as primeiras tivessem acesso às segundas devem-se aos aspectos sociais, forjados nos braços do patriarcado que procurava afastar o sexo feminino do âmbito intelectual. Conforme explica Didier (apud Figueiredo, 2013), "a escrita feminina constitui um ponto de tensăo entre o desejo de escrever e uma sociedade que manifesta [...] uma hostilidade sistemática ou de forma atenuada (ironia ou depreciaçâo)" (p. 72). Ainda na contemporaneidade, conseguimos visualizar essa hostilidade contra os escritos das mulheres, por meio das barreiras encontradas no mercado editorial, e até mesmo nas premiaçōes literárias, pois a ficçáo de autoria feminina náo atinge mais do que $20 \%$ do total de prêmios distribuídos, como procuramos demonstrar por meio das reflexóes suscitadas nesse artigo.

O campo literário, o cânone e as premiaçōes literárias têm servido aos pressupostos patriarcais, pois săo grandes as dificuldades que as escritoras precisam superar para adentrar esses domínios intelectuais. Gradativamente, as mulheres que escrevem vâo se inserindo nesses âmbitos, por meio das brechas que anos de resistência e luta acabaram por escavar. Daí a importância da pesquisa acerca dos trabalhos de escritoras, o que propicia "visibilidade à autoria feminina e assim, reconstruir a voz da mulher e suas representaçôes" (SCHMIDT, 1999, p. 37), que durante tanto tempo foi moldada a partir da ótica masculina. Está na hora de deixar as mulheres falarem por si mesmas e, por isso, é fundamental saber ouvi-las. 


\section{REFERÊNCIAS}

ABREU, Márcia. Cultura letrada: literatura e leitura. Săo Paulo: Editora Unesp, 2006. $125 \mathrm{p}$.

BIBLIOTECA NACIONAL. Prêmio Camōes de Literatura. 2019. Disponível em: https:// www.bn.gov.br/explore/premios-literarios/premio-camoes-literatura Acesso em: 28 fev. 2020.

BOURDIEU, Pierre. A dominaçâo masculina. 13. ed. Rio de Janeiro: Bertrand Brasil, 2015. $160 \mathrm{p}$.

BOURDIEU, Pierre. As regras da arte: gênese e estrutura do campo literário. Săo Paulo: Companhia das Letras, 1996. 431 p.

CANDIDO, Antonio. Direitos humanos e literatura. Săo Paulo: Brasiliense, 1989.

DALCASTAGNE, Regina. A personagem do romance brasileiro contemporâneo: 19902004. Estudos de Literatura Brasileira Contemporânea, n. ${ }^{\circ} 26$. Brasília, julho-dezembro de 2005, pp. 13-71.

DIDIER, Béatrice. L'écriture-femme. Paris: PUF, 1981.

DUARTE, Constância Lima. O cânone e a autoria feminina. In: SCHMIDT, Rita Terezinha (org.). Mulheres e literatura: (trans)formando identidades. Porto Alegre: Universidade Federal do Rio Grande do Sul, 1997. pp. 53-60.

FIGUEIREDO, Eurídice. Mulheres ao espelho: autobiografia, ficçăo, autoficçăo. Rio de Janeiro: Eduerj, 2013. 246 p.

MICELI, Sérgio. Nacional estrangeiro: história cultural e social do modernismo artístico em Săo Paulo. Săo Paulo: Companhia das Letras, 2003.

MUZART, Zahidé Lupinacci. A ascensăo das mulheres no romance. In: ALVES, Aline et al. A escritura do feminino: aproximaçōes. Florianópolis: Editora Mulheres, 2011. pp. 17-27.

PRATT, Mary Louise. Don't interrupt me: The gender essay as conversation and countercannon. Revista Brasileira de Literatura Comparada, n. 4, 1998.

PRÊMIO JABUTI. Premiados por ediçăo. 2019. Disponível em: <https://www.premiojabuti.com.br/premiados-por-edicao/>. Acesso em: 28 fev. 2020.

PRÊMIO MACHADO DE ASSIS. Prêmios Literários da ABL. 2019. Disponível em: <http:// www.academia.org.br/academia/premios>. Acesso em: 12 fev. 2019.

REIS, Roberto. Cânon. In: JOBIM, José Luis (org.). Palavras da crítica. Rio de Janeiro: Imago, 1992. pp. 65-92.

SCHMIDT, Rita Terezinha. Na literatura, mulheres que reescrevem a naçăo. In: HOLLANDA, Heloisa Buarque de (org.). Pensamento feminista brasileiro: formaçâo e contexto. Rio de Janeiro: Bazar do Tempo, 2019. pp. 65-79.

SCHMIDT, Rita Terezinha. Recortes de uma história: A construçáo de um fazer/saber. In: RAMALHO, Christina (org.). Literatura e feminismos: propostas teóricas e reflexôes críticas. Rio de Janeiro: Elo, 1999. pp. 23-40. 
VITÓRIA, Carla; ZELIC, Helena. A cultura das mulheres muda o mundo. In: MORENO, Renata (org.). Reflexóes e práticas de transformaçáo feminista. Sáo Paulo: Sempreviva Organizaçāo Feminista, 2015. pp. 75-95.

WOOLF, Virginia. Um teto todo seu. Sáo Paulo: Tordesilhas, 2014. 189 p.

XAVIER, Elódia. Para além do cânone. In: RAMALHO, Christina (org.). Literatura e feminismos: propostas teóricas e reflexóes críticas. Rio de Janeiro: Elo, 1999. pp. 15-22.

ZOLIN, Lúcia Osana. O habitus e o espaço dos possíveis: a literatura de autoria feminina paranaense/brasileira. In: VÁSQUEZ, Raquel Bello (org.) et al. Estudos da AIL em Literatura, História e Cultura Brasileiras. Coimbra: Ail Editora, 2015. pp. 103-108. 